The University of San Francisco

USF Scholarship: a digital repository @ Gleeson Library |

Geschke Center

2014

\title{
Corporate Social Responsibility: Perspectives of Hotel Frontline Employees
}

Sun-Young Park

University of San Francisco, sypark5@usfca.edu

Stuart E. Levy

Follow this and additional works at: http://repository.usfca.edu/esib

Part of the Business Commons

\section{Recommended Citation}

Sun-Young Park, Stuart E. Levy, (2014) "Corporate social responsibility: perspectives of hotel frontline employees", International Journal of Contemporary Hospitality Management, Vol. 26 Iss: 3, pp.332 - 348. DOI: 10.1108/IJCHM-01-2013-0034.

This Article is brought to you for free and open access by the School of Management at USF Scholarship: a digital repository @ Gleeson Library | Geschke Center. It has been accepted for inclusion in Entrepreneurship, Innovation, and Strategy by an authorized administrator of USF Scholarship: a digital repository@ Gleeson Library | Geschke Center. For more information, please contact repository@usfca.edu. 


\section{Corporate Social Responsibility: Perspectives of Hotel Frontline Employees}

\section{Sun-Young Park}

School of Management, University of San Francisco, San Francisco, California, USA,

and

\section{Stuart E. Levy}

School of Business, George Washington University, Washington, DC, USA

- Purpose: This study examines hotel frontline employees' perceptions of Corporate Social responsibility (CSR) activities at the hotel they currently work, and how their perceptions influence their level of Organizational Identification, an indicator of their relationship quality with the hotel.

- Design/methodology/approach: This study uses 575 responses of hotel frontline employees in the U.S., collected through a national online survey.

- Findings: Results show that hotel employees' perceptions of CSR activities encompass the host community, colleagues, and customers, beyond green practices. Moreover, their perceptions of CSR activities positively and significantly influence the level of Organizational Identification.

- Research limitations/implications: The results of this exploratory study should not be generalized to all frontline employees in the U.S. hotel industry. Future studies should extend this study to examine potential relationships among other variables relevant to Organizational Identification, and in other hospitality industry contexts. Also, this study does not seek to question the merits of CSR per se, as it takes a managerial perspective to assist hoteliers' understanding of and decision-making on CSR.

- Practical implications: As CSR activities often represent company values and norms, frontline employees' perceptions of them can influence how they identify with the company, which is an impetus for their attitudinal and behavioral support to help achieve the company's goals. Accordingly, CSR activities can be a critical tool in engaging frontline employees to achieve better performance and derive more meaning in their careers, and in attracting good quality employees.

- Originality/value: This study is a first attempt to empirically examine how CSR activities can benefit hotel employees, based on various literatures on service-profitchain, $C S R$, and social identity theory.

Keywords: corporate social responsibility; hotel frontline employees; organizational identification. 


\section{INTRODUCTION}

While interest in, and practices of, Corporate Social Responsibility (CSR) in the hospitality industry are growing, our current understanding of CSR in the hospitality literature is limited (Sheldon and Park, 2011). In the hotel industry, environmental efforts or "greening" have dominated CSR activities, given the cost-saving nature of green practices such as linen and towel re-use programs or installation of energy and water-efficient guestroom fixtures (Levy and Park, 2011).

However, CSR encompasses other initiatives beyond the environment, concerning consumers, community and employees (e.g., Carroll, 1999; Clarkson, 1995; Wood, 1991). Particularly, a hotel firm's relationship with its employees can directly influence consumer reactions to it and its profitability. For instance, employee boycotts over labor disputes at several city-center hotels led to the cancellation of conferences representing approximately 5,000 potential attendees (Wernau, 2010). As such, the way employees perceive of their firm's CSR activities can influence the relationship quality between employees and the firm (Bhattacharya, et al., 2008).

Meanwhile, despite the touted benefits of CSR on employees (e.g., increased morale), how employees' perceptions of CSR influence their attitudes and behavior have not been examined in the hospitality industry context. Given that CSR programs often represent company values and norms, employees' perceptions of them can influence how employees identify with the firm, which is an impetus for employees' attitudinal and behavioral support to help achieve the firm's goals (e.g., Bartel, 2001; Dutton et al., 1994; Mael and Tetrick, 1992).

The hospitality industry is often characterized as a labor-intensive, people-focused, service industry (e.g., Guillet and Mattila, 2010; King et al., 2011; Tepeci, 1999) in which frontline employees are critical to the firm's success (e.g., Clark et al., 2008; Tsaur and Lin, 2004). Numerous studies have shown that employee attitudes and performance have a major influence on how consumers evaluate service quality, value, satisfaction, and repeat patronage (e.g., Bitner, 1990; Chi and Gursoy, 2009; Hartline and Jones, 1996; Liao and Chuang, 2004; Smith et al., 1999). Moreover, the service-profit chain model (Heskett et al., 2008) illustrates that employee attitudes and behavior in service industries are ultimately linked to firm profit. 
Employees help realize many of their firms' CSR activities by carrying them out in daily operations, and are influenced by workplace policies involving the community and environment in which employees reside. This is of particular importance to the hotel industry, in which employee turnover has averaged 76.8 percent per year compared to 56.2 percent in the retail service sector between 2001 and 2010 (U.S. Bureau of Labor Statistics, 2011). Considering the relatively high turnover rate in the hospitality industry and the potential benefits of CSR for employees, it is important to understand how employees' perceptions of CSR may influence their attitudes toward the firm, which has yet to be explored. Accordingly, this study aims to investigate this research gap to help hotel executives deepen the understanding of the impacts of CSR activities from the frontline employee's perspective, which are considerably, yet often invisibly, linked to firm performance and social wellbeing.

\section{LITERATURE REVIEW}

\section{Corporate Social Responsibility and Hospitality Industry}

The origin of CSR can be traced back to at least three sources, indicating the long illustrious history of this topic: Dodd's (1932) argument for firms' responsibility toward society beyond shareholders (cited in Cochran, 2007), Bowen's (1953) book 'Social Responsibilities of Businessman' (cited in Carroll, 1999) whom Carroll (1999) called, the "Father of Corporate Social Responsibility" (p. 270), or Boulding's general systems theory (1956) in regards to CSR measurements (cited in Wood, 2010). Although there are many definitions of CSR exist, they commonly refer to the relationship between businesses and society, which denotes firms' actions to balance financial performance, impacts on society and the environment. These corporate activities are often voluntary and/or beyond legal obligations (Carroll, 1999; McWilliams and Siegel, 2001). Other terms that are used with a similar meaning include: Corporate Responsibility, Corporate Citizenship, Corporate Sustainability, Corporate Conscience, Sustainable Business, Ethical Business, and Responsible Business.

In addition, CSR has been approached with diverse theories: stewardship theory (Davis et al., 1997); stakeholder approach (Freeman, 1984; Jones, 1995; Roberts, 1992; Shropshire and Hillman, 2007), institutional theory (Campbell, 2007; Husted and Allen, 2006; Jennings and 
Zandbergen, 1995), and resource-based view (Russo and Fouts, 1997), or a combination of several theories (e.g., Aguilera, et al., 2007; Chen and Roberts, 2010; Wheeler, et al., 2003).

Meanwhile, CSR is a contested concept and there exist critical perspectives. For example, Friedman (1970) and Levitt (1958) famously warned businesses not to be concerned with 'social' issues, because the primary purpose of business is to make profits. Similarly, it has been also argued that CSR is not a useful concept in practice for business managers (e.g., Freeman \& Liedtka, 1991; Porter \& Kramer, 2011), because the concept inherently separates business and society, imposing businesses to be accountable for social ills, beyond their economic role in society (i.e., creating wealth).

Nevertheless, CSR has become an important matter for businesses, in recent years, in the wake of global problems such as climate change, the depletion of natural resources, supply chain issues, coupled with financial scandals and economic crises. Annual industry surveys (e.g., Kiron, et al., 2013; PricewaterhouseCoopers or PwC, 2011) reported that managers now recognize CSR and sustainability as "essential" for strategic operations, innovations, and talent management. Similar to Kiron et al. (2013) emphasized, "Sustainability is both a business necessity and an opportunity (p. 12), PwC contended, "Corporate responsibility is not an altruistic nice-to-have, but a business imperative" (p. 121). CSR is not a recent phenomenon for the lodging industry. In fact, the American Hotel and Motel Association's Code of Operating Practices emphasized ethical and responsible operations since the 1970s. However, faced with the global challenges, particularly in recent years, many hotels have begun practicing various CSR activities. For instance, in an extensive review of company reports, websites, and literature, Levy and Park (2011) identified 129 CSR activity items currently practiced by 10 hotel companies with the largest number of rooms in the world.

These variety of CSR activities reflect the concept's multi-dimensionality, often categorized by the 'aspects' of responsibilities, or "structural principles" (Wood, 2010, p. 50) economic, legal, ethical, and discretionary (or philanthropic) responsibilities (Carroll, 1999; Wood, 1991, 2010). These were then categorized based on 'to whom' (stakeholders) the firm is responsible. Stakeholders refer to individuals or groups who "have or claim, ownership, rights, or interests in a corporation and its activities" (Clarkson, 1995, p. 106) and thus "can affect or are affected by the achievement of the organization's objectives" (Freeman, 1984, p. 46). Depending on the group's relationship with the firm's survival as a going concern, they can be either 
primary stakeholders such as customers, employees, community, government, or secondary such as activists (Clarkson, 1995).

\section{Corporate Social Responsibility and Employees}

CSR activities have found to positively influence attitudes and behavior of employees, who are considered critical internal stakeholders (e.g., Clarkson, 1995; Kim et al., 2010). CSR activities increase commitment and morale of current employees and increase retention rates (Brokaw, 2009; Galbreath, 2010; Maignan et al., 1999; Porter and Kramer, 2006; Peterson, 2004; Rupp et al., 2006; Rego et al., 2010; Turker, 2009b). Although financial outcomes may not be instantaneous, the positive effects of CSR on internal stakeholder attitudes and behavior imply the long-term "economic benefits" to the firm, through "favorable treatment in the press, the ability of the firm to attract and manage superior management and staff personnel" (Murray and Vogel, 1997, p. 154).

Firms' good CSR performance can also signal attractive workplace conditions, contributing to positive corporate image and reputation, which tends to help attract good quality employees (Albinger and Freeman, 2000; Greening and Turban, 2000; Bhattacharya et al., 2008; McWilliams and Siegel, 2001; Porter and Kramer, 2006; Turban and Greening, 1997). While the importance of CSR should not be over-emphasized for recruitment (Auger, et al., 2013), the survey of 4,000 millennials from 44 countries by PwC (2011) found that future workforce consciously seek employers whose corporate responsibility behaviors reflect their own values ( $88 \%$ of the respondents), and consider an employer's policy on climate change and environment important, when choosing an employer (58 percent of the respondents).

The firm's relationship with employees via CSR activities is influenced by the employee perceptions of CSR activities - how effective the employees think those activities are in benefiting the cause beneficiaries and/or society (Bhattacharya et al., 2009). However, no previous research within the hospitality industry context has evaluated CSR activities from the employees' perspective, particularly, that of frontline employees who closely interact with customers. Moreover, there has yet to be research on how hospitality industry employees' perceptions of their firms' CSR activities influence their attitudes at work, which would help us understand how CSR benefits employees within a firm. 
According to social identity theory (Tajfel and Turner, 1986), when an employee perceives a firm's characteristics appealing and akin to his/her self-identity, s/he identifies with it to be an extension of personal identity. As an employee categorizes oneself into a group (e.g., the firm) with affinity, self-categorization theory (Turner, 1984) asserts that $\mathrm{s} / \mathrm{he}$ supports the positive characteristics of the group by internalizing and following group's mission, norms and values (Ashforth and Mael, 1989; Kelman, 1958), and behaves cooperatively and collaboratively toward the firm's goals (Ashforth and Mael, 1989; Collier and Esteban, 2007; Dutton et al., 1994; Turner, 1984).

As firms strive to project their citizenship in society by practicing diverse initiatives and programs designed to benefit various stakeholders that they consider critical, CSR activities reflect the firm's characteristics (e.g., values, norms, ethics). Consequently, an employee's perceptions of his/her company's CSR activities would reflect his/her attitudes toward this particular social group's norms and values that the employee categorizes oneself into as a member of the group. When an employee positively perceives the firm's values and its initiatives (e.g., CSR programs), s/he would feel closer to the firm and co-workers, and be more likely to exert efforts to accomplish the objectives of the group with which s/he identifies.

The concept based on social identity theory is Organizational Identification (OI), which refers to the group member's perceived affinity with and sharing experiences with an organization where s/he belongs to and where his/her personal identity is defined in reference to the group characteristics (Ashforth and Mael, 1989; Gautam et al., 2004; Mael and Ashforth, 1992; Mael and Tetrick, 1992). Based on social identity theory and self-categorization theory, the concept of $O I$ was also found to be different from other related concepts such as job satisfaction and occupational/work group attachment, according to Riketta's (2005) metaanalysis of 95 studies and other empirical tests (e.g., Gautam et al., 2004; Mael and Tetrick, 1992).

At the time of this study, however, no research on this topic exists in the hospitality context. OI has been found to be a significant driver of group members' attitudinal and behavioral support, helping achieve group objectives, performance, and lowering intentions to leave (e.g., Bartel, 2001; Dutton et al., 1994; Mael and Tetrick, 1992; Mael and Ashforth, 1992; Riketta, 2005; van Dick et al., 2004; van Dick et al., 2005; van Knippenberg, 2000), reflecting the quality of employees' relationships with the firm (Bhattacharya et al., 2008). Few studies, 
however, have examined how employees' perceptions of CSR are related to their degree of identification with the firm to understand the psychological impacts of CSR on employees. Therefore, this study's research questions are: 1) how do frontline employees perceive of their hotel CSR activities? and 2) how do frontline employees' perceptions of their hotel CSR activities influence their level of $O I$ ?

\section{METHOD}

The survey was pre-tested with 15 business school faculty and graduate students to achieve more brevity and clarity, and then distributed via email to an online panel of hotel employees in the U.S. Recipients were confirmed panel subscribers of Qualtrics, the company that distributed the survey on our behalf. Participants were limited to a predetermined, customized respondent group -hotel employees throughout the U.S. The online survey was open from September 20 to November 18, 2011, and the potential respondents were reminded of participation three times during that time. We included screening questions to select hotel frontline employees -those who reported having a high or medium level of guest interactions, and having non-managerial and non-supervisory responsibilities. As a result, 575 responses in total were used for this study. Respondents were asked to indicate their perceptions of CSR activities of the hotel where they currently work, level of Organizational Identification, and demographic information.

Measures of CSR activities were developed based on an extensive literature review on corporate social responsibility activity items (e.g., Carroll, 1999; Clarkson, 1995; Lindgreen et al., 2009; Spiller, 2000, Turker, 2009a; Wood, 1991, 2010). In addition, CSR activities of the ten largest hotel companies according to a 2010 Hotels Magazine survey were reviewed and supplemented from their CSR reports and websites, following the method used by Holcomb, et al. (2007, 2010). The CSR items, 129 in total, from the literature and hotel reports were identified by three researchers independently, coded, and synthesized to 35 relevant items, following the approach used by Levy and Park (2011). For this study, the survey items were further reduced to 22 activities based upon their applicability to frontline employees.

Previous studies suggest that CSR activities are better understood theoretically and tested empirically when they are organized by stakeholder types (e.g., customers, employees, etc.) 
rather than responsibility types (e.g., economic, legal, etc.), since activity items categorized by responsibility type include those pertaining to multiple stakeholders, preventing a clear investigation about the activities linked with intended stakeholders or beneficiaries (Clarkson, 1995; Lindgreen et al., 2009; Rego et al., 2010; Spiller, 2000; Turker, 2009a, 2009b; Waddock, 2004).

A total of $22 C S R$ activities related to the environment, community, employees, and customers, were measured on a scale of five-point Likert-type scale, ranging from 1 'Strongly Disagree' to 5 'Strongly Agree', while 3 indicated 'Neither Agree or Disagree.' An option for "Not Applicable" was also provided. Following previous studies (Lindgreen et al., 2009; Spiller, 2000, Turker, 2009a), respondents were asked to indicate their opinion on the five-point scale about each of the 22 statements (i.e., CSR items) regarding the hotel in which they currently work, whereby each item was randomly presented to the respondent. For instance, the items were stated, "My hotel incorporates the interests of customers in business decisions," and "My hotel encourages employees to develop their skills and careers," and so on.

Organizational Identification $(O I)$ was measured with nine items obtained from Mael and Tetrick's study (1992), which have been verified for validity and reliability, and found to be most representative of the concept in a meta-analysis, and is a "most often used scale" (Riketta, 2005, p. 374). The original two-factor scale consists of six items for Shared Experience (SE), denoting the perception of what happens to the organization that one belongs to as personal experience, and four items for Shared Characteristics $(S C)$, referring to the perception of the characteristics of the organization that one belongs to as personal characteristics. However, the result of Mael and Tetrick's study (1992) showed a very low loading (.19) of one of the items for the second factor, which was excluded in this study.

The data were analyzed using SPSS version 19 to obtain the construct components of $C S R$ and $O I$. Then, stepwise regression analysis was used with the factor scores from principal component analysis with the varimax rotation method to examine the effects of CSR dimensions on those of $O I$. Non-response bias was tested by comparing early vs. late respondents on each measure (Armstrong and Overton 1977), and the result showed no differences. To reduce any potential common method bias such as priming effects, item/context-induced mood states, or halo effects, we made our survey questions randomly displayed to respondents who were 
national online panel members (i.e. not limited to certain companies), and guaranteed response anonymity in the introduction of our survey (Bagozzi and Yi, 1990; Podsakoff et al., 2003).

\section{RESULTS}

As shown in Table 1, the respondents were currently employed at hotels full-time $(70.1 \%)$ or part-time $(29.9 \%)$ in various positions (e.g., food and room service, front desk/customer service, casino, maintenance). The average age of respondents was 38 $(\mathrm{SD}=12.6)$, and nearly three-quarters were female. Respondents had five years $(\mathrm{SD}=7.43)$ of work experience at their current hotel on average and over eight years $(\mathrm{SD}=5.16)$ in the hotel industry. Over 60 percent of the respondents had not obtained college degrees. No significant correlation was found between demographic variables (i.e., industry tenure, organizational tenure, age, gender) and $O I$, unlike the results of studies in non-hospitality industry contexts (e.g., Riketta, 2005).

Table 1

The Respondent Profile ${ }^{a}$

\begin{tabular}{lrr}
\hline Characteristics & $\mathrm{N}$ & $\begin{array}{r}\text { Percentage } \\
(\%)\end{array}$ \\
\hline Employment Status & & \\
Full-time & 403 & 70.1 \\
Part-time & 172 & 29.9 \\
Areas of Work & & \\
Food/room service & 247 & 43 \\
Front desk/customer service & 172 & 29.9 \\
Other (casino, maintenance, shuttle, & & \\
etc.) & 73 & 12.7 \\
Housekeeping & 63 & 11 \\
Reservations/sales & 15 & 2.6 \\
Bellstaff & 5 & 0.9 \\
Gender & & \\
Male & 65 & 36.9 \\
Female & 176 & 73.0 \\
Education Level & & \\
9th to 12th grade, no diploma & 6 & 2.5 \\
High school graduate & 58 & 24.1 \\
Some college, no degree & 85 & 35.3 \\
Associate's degree & 43 & 17.8 \\
Bachelor's degree & 44 & 18.3 \\
Graduate or professional degree & 5 & 2.1 \\
\hline
\end{tabular}


${ }^{a}$ Valid totals differ between employment status / areas of work $(n=575)$ and gender / education level $(n=241)$

Respondents' perceptions toward hotel CSR activities on average ranged from 3.45 $(\mathrm{SD}=1.2)$ to $4.52(\mathrm{SD}=0.86)$ (Table 2$)$. Overall, respondents' perceptions of their hotel being responsive and responsible were more positive for the needs of customers and employees than for those of the environment or community. These CSR perception items resulted in three dimensions: CSR-Environment and Community (11 items; $\alpha=.947)$; CSR-Employees (six items; $\alpha=.921$ ); and CSR-Customers (five items; $\alpha=$.849) (Table 3).

Table 2

Descriptive Statistics: Hotel Frontline Employee Perceptions of CSR Activities

\begin{tabular}{llc}
\hline CSR item & Mean & SD \\
\hline Customer satisfaction is highly important for my hotel. & 4.52 & 0.86 \\
One of the main principles of my hotel is to provide high-quality services and products & 4.42 & 0.99 \\
to our customers. & 4.38 & 0.85 \\
My hotel is responsive to the complaints of our customers. & 4.14 & 0.99 \\
My hotel provides a safe and healthy working environment to all employees. & 4.08 & 1.03 \\
My hotel incorporates the interests of customers in business decisions. & 4.07 & 1.12 \\
My hotel respects consumer rights beyond legal requirements. & 3.97 & 1.22 \\
My hotel treats our employees fairly and respectfully. & 3.89 & 1.13 \\
My hotel encourages employees to develop their skills and careers. & 3.86 & 1.09 \\
My hotel's policies encourage a good work and life balance for employees. & 3.78 & 1.07 \\
My hotel incorporates the interests of community in business decisions. & 3.72 & 1.15 \\
My hotel financially supports local charities through financial donations, sponsoring & 3.68 & 1.06 \\
events, and/or providing goods and services. & 3.65 & 1.16 \\
My hotel actively attempts to purchase products and services which minimize & 3.63 & 1.08 \\
environmental impacts. & 3.61 & 1.13 \\
My hotel provides employees with fair and reasonable salaries. & 3.59 & 1.12 \\
My hotel actively attempts to minimize the environmental impact of the hotel's & 3.59 & 1.10 \\
activities. & 3.54 & 1.13 \\
My hotel financially supports environmental initiatives of other organizations. & 3.54 & 1.23 \\
My hotel incorporates environmental concerns in business decisions. & 3.52 & 1.17 \\
My hotel helps improve the quality of life in the local community. & 3.45 & 1.06 \\
My hotel encourages guests to reduce their environmental impact through programs & 3.45 & 1.20 \\
\hline and initiatives. & & \\
My hotel encourages employees to be actively engaged in local community & & \\
organizations. & & \\
My hotel reports on the hotel's environmental performance. & & \\
My hotel actively works with international organizations which promote responsible & & \\
business. & & \\
My hotel incorporates the interests of employees in business decisions. & & \\
\hline
\end{tabular}


Table 3

Hotel Frontline Employee Perceptions of CSR Activities ${ }^{a}$

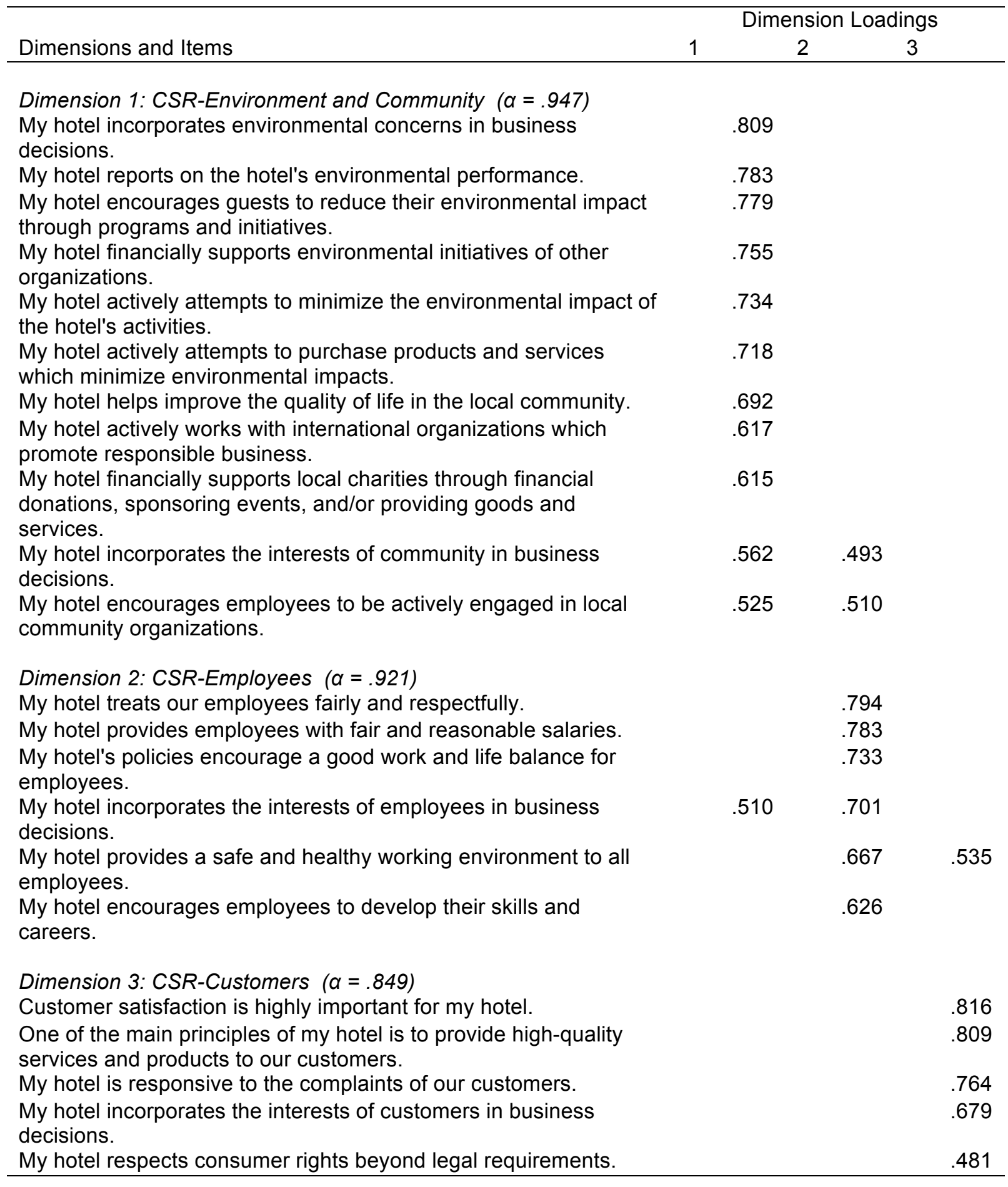

${ }^{a}$ Kaiser-Meyer-Olkin Measure of Sampling Adequacy=.949; Extraction Method: Principal Dimension Analysis; Rotation Method: Varimax with Kaiser Normalization; Rotation converged in 7 iterations. Total 69.5\% variance explained. 
For the concept, $O I$, the data resulted in two dimensions, explaining 69.5 percent of the total variance - seven items for $S E$, and two items for $S C$ (Table 4). Compared to Mael and Tetrick's (1992) original model, four items were loaded on different dimensions, although these seem to make reasonable sense. For example, the item, "To a great extent, I act like a typical person employed in my hotel" was loaded on $S C$ rather than $S E$. Nonetheless, this item can be interpreted to be very similar to the item, "I don't act like a typical person employed in my hotel" (which was reverse-coded), and it seems reasonable for these items to belong to the same dimension, $S C$. The two items, "If a story in the media criticizes my hotel, I would feel embarrassed" and "I have a number of qualities typical of people employed in my hotel," were loaded on $S E$, not $S C$. The feeling of embarrassment when the hotel in which one works is criticized, can be interpreted as having a $S E$ rather than $S C$. Similarly, the feeling of sharing typical qualities with colleagues may also be perceived as more experiential in nature.

Table 4

Hotel Frontline Employees' Organizational Identification ${ }^{a}$

\begin{tabular}{lc}
\hline & \multicolumn{2}{c}{$\begin{array}{c}\text { Dimension } \\
\text { Loadings }\end{array}$} \\
Dimensions and Items & 1 \\
\hline & \\
Dimension 1: Shared Experience & .874 \\
When someone praises my hotel, it feels like a personal compliment. & .873 \\
I am very interested in what others think about my hotel. & .863 \\
My hotel's successes are my successes. & .842 \\
When someone criticizes my hotel, it feels like a personal insult. & .807 \\
When I talk about my hotel, I usually say, "we" rather than "they." & .784 \\
If a story in the media criticizes my hotel, I would feel embarrassed. & .666 \\
I have a number of qualities typical of people employed in my hotel. & \\
& \\
Dimension 2: Shared Characteristics & .797 \\
I don't act like a typical person employed in my hotel. (REVERSE coded) & .692 \\
To a great extent, I act like a typical person employed in my hotel. & \\
\hline & \\
Kaiser-Meyer-Olkin Measure of Sampling Adequacy=.907; Extraction Method: Principal Dimension Analysis; \\
Rotation Method: Varimax with Kaiser Normalization; Rotation converged in 3 iterations; Total 69.47\% variance \\
\end{tabular}

Finally, we examined how hotel frontline employees' perceptions of CSR influenced the degree of identification with their hotel. Results (Tables 5) showed that all three dimensions of 
CSR had positive and significant effects on SC, the first dimension of OI (CSR-Employees $\beta=.463 ;$ CSR-Environment and Community $\beta=.366$; CSR-Customers $\beta=.327$; Adjusted $\mathrm{R}^{2}=.424$ ), while only one dimension (CSR-Customers) had a positive and significant effect on the second dimension of $O I(S C ; \beta=.167)$. This means that the more positively that hotel frontline employees perceived CSR activities, the more they were interested in what others think about their hotel; identified their hotel's success with their own success; and felt personally insulted when others criticize their hotel. Although the total explained variance was very small (Adjusted $\mathrm{R}^{2}=.022$ ), results showed that the more positively that frontline employees perceived their hotel's CSR activities concerning customers (e.g., the hotel respects consumer rights beyond legal requirements; the hotel incorporates customers' interests in business decisions), the more that employees thought they share similar characteristics with co-workers and the hotel.

Table 5

Influence of CSR Activities on Organizational Identification (Shared Experience ${ }^{\mathrm{a}}$ and Shared Characteristics ${ }^{\text {b }}$ )

\begin{tabular}{|c|c|c|c|c|c|}
\hline $\begin{array}{c}\text { Dependent } \\
\text { Variable }\end{array}$ & Model & & $\begin{array}{l}\text { Standardized } \\
\text { Coefficients } \\
\text { (b) }\end{array}$ & $\mathrm{t}$ & Sig. \\
\hline Shared & 1 & (Constant) & & -0.816 & .416 \\
\hline Experience & & EMPLOYEES & .446 & 6.425 & $0.00^{*}$ \\
\hline (Dimension 1 of & 2 & (Constant) & & -0.927 & .355 \\
\hline \multirow{6}{*}{ Identification) } & & EMPLOYEES & .457 & 7.157 & $0.00^{*}$ \\
\hline & & ENVIRONMENT \& COMMUNITY & .359 & 5.617 & $0.00^{*}$ \\
\hline & 3 & (Constant) & & -1.26 & .209 \\
\hline & & EMPLOYEES & 463 & 7.881 & $0.00^{*}$ \\
\hline & & ENVIRONMENT \& COMMUNITY & .366 & 6.221 & $0.00^{*}$ \\
\hline & & CUSTOMERS & .327 & 5.569 & $0.00^{*}$ \\
\hline Shared & & (Constant) & & .281 & .779 \\
\hline Characteristics & & CUSTOMERS & .167 & 2.187 & $.03^{*}$ \\
\hline (Dimension 2 of & & ENVIRONMENT \& COMMUNITY & -.008 & -0.107 & .915 \\
\hline $\begin{array}{l}\text { Organizational } \\
\text { Identification) }\end{array}$ & & EMPLOYEES & .065 & .846 & .399 \\
\hline
\end{tabular}

\footnotetext{
${ }^{a}$ Dependent variable: Shared Experience (Dimension 1 of Organizational Identification); Adjusted $\mathrm{R}^{2}=.424 ;{ }^{*} \mathrm{p}<.05$.
}

${ }^{\mathrm{b}}$ Dependent variable: Shared Characteristics (Dimension 2 of Organizational Identification); Adjusted $\mathrm{R}^{2}=.022 ;{ }^{*} \mathrm{p}<.05$. 


\section{IMPLICATIONS AND CONCLUSION}

In this study, we examined how frontline employees perceive CSR activities of the hotels where they currently work, and how their perceptions influence the way they identify with the hotel. As frontline employees are ambassadors and practitioners of organizational values, beliefs, and norms, their attitudes and behavior toward the hotel not only influence job performance and the firm's performance, but also their own wellbeing as a community member where the hotel operates.

The study's empirical results imply that hotel managers should go beyond 'greening' when considering CSR activities, as employees identify with the hotel through not only CSR activities concerning the environment but also through those concerning community, employees, and customers. The employee dimension of CSR most strongly contributed to the shared experience component of organizational identification, while the customer dimension of CSR was the only significant dimension contributing to the shared characteristics component of organizational identification. Furthermore, none of the top ten CSR activities as perceived by frontline employees (Table 2) were environmental in nature. Accordingly, hoteliers should maintain a more holistic perspective when identifying potential $C S R$ initiatives. We strongly encourage hoteliers to review existing good CSR practices in the lodging industry, which are featured in academic and trade publications (e.g., Diener et al., 2009; Singh and Houdre, 2012). Alternatively, hotels can participate in certification and reporting programs (e.g., Green Globe, Global Reporting Initiative) or consult experts for a deeper level of guidance and execution.

Results indicated that hotels should foster an organizational culture in which CSR activities are positively perceived by employees, and align them with societal and guest expectations (Ralston, 2010). In other words, a prerequisite for the positive virtuous cycle effects of CSR activities is for hotels to engage in CSR activities that their employees, a primary internal stakeholder group, perceive positively (Bhattacharya et al., 2008; Maignan et al., 1999; Peterson, 2004; Rupp et al., 2006; Turker, 2009b). While the extent to which hospitality firms engage employees in CSR activities is unknown, IBM's global survey (Pohle and Hittner, 2008) found that 69 percent of 250 business executives reported that they do not involve their employees in $C S R$ initiatives. For $C S R$ activities to have the espoused positive effects on customers and society, the hotel industry should recognize the importance of employees' 
perceptions of those activities, which is closely connected to their frontline employees' work attitudes and behavior.

Accordingly, hotels should engage and consult frontline employees as an overall CSR strategy is developed and potential activities are reviewed, chosen and implemented. This way, hotels can improve CSR-related communications with employees to strengthen employeeemployee relationship quality. Internal marketing approaches can include online efforts such as incorporating CSR activities and successes on employee-focused corporate website pages and blogs as well as social networking platforms and email newsletters. The interactive nature of the digital format can also enhance the opportunity to engage with employees. Offline tools might include discussion with employees of good CSR practices during daily meetings, while monitoring of CSR activity successes can be visually featured in employee break rooms and in printed collateral.

It should be noted that our study sample may not be entirely representative of the entire hotel industry of frontline employees in the United States. Despite the increasing utilization of online surveys for research (Lozar Manfreda et al., 2008), our use of an online panel may have limited the scope to those who use a computer and are proficient in English. As mentioned above, although we made every effort to reduce any potential bias from the method we used, social desirability may have been in effect, like in many social science studies. We recommend that future studies should test for social desirability by including the scale in survey to examine its influence on the relationships among variables.

In addition, to enhance our understanding about internal mechanisms of how CSR activities work among employees, future studies should extend this study to examine potential relationships among other variables relevant to Organizational Identification (OI), and in other hospitality industry contexts such as restaurants. For example, are there gender or other demographic differences associated with OI? How are hospitality industry frontline employees' perceptions of CSR and their level of $O I$ related to their job performance, satisfaction, trust, and retention? Do the employees who positively perceive their firm's CSR activities and closely identify with the firm and co-workers tend to be happier, stay with the firm longer, and spread positive word-of-mouth about the firm? Job satisfaction might mediate $O I$ in predicting turnover intentions as found by van Dick et al. (2004). In the hospitality context concerning employees' perceptions of the firm, trust was found to influence employee satisfaction (e.g., Chathoth et al., 
2007). Studies on hotel frontline employees found a significant effect of employee satisfaction on affective commitment and turnover intentions (e.g., Karatepe and Kilic, 2007). Accordingly, OI may be an antecedent of employee satisfaction and affective commitment, which in turn predicts turnover intentions.

As the hospitality industry's retention rate is relatively low, and younger members of the hospitality industry workforce have reported lower commitment, higher turnover intentions, and less positive perceptions about their work than their older colleagues (e.g., Lub et al., 2012), CSR activities may be able to serve as an effective and foundational means for hospitality firms to strengthen relationships with employees, reflecting the firm's values and norms. The positively perceived CSR activities can also help employees realize their altruistic values which are considered to be important by all generational hospitality workforce (Chen and Choi, 2008). $C S R$ activities may further appeal to future employees who wish to make positive social and environment impacts through their work and find a deeper sense of meaning in their careers (Zukin and Szeltner, 2012). 


\section{REFERENCES}

Aguilera, V., Rupp, D., Williams, C. and Ganapathi, J. (2007), "Putting the S back in corporate social responsibility: a multilevel theory of social change in organizations", Academy of Management Review, Vol. 32 No. 3, pp. 836-563.

Albinger, H. and Freeman, S. (2000), "Corporate social performance and attractiveness as an employer to different job seeking populations", Journal of Business Ethics, Vol. 28 No. 3, pp. 243-53.

Armstrong, J. and Overton, T. (1977), "Estimating nonresponse bias in mail surveys", Journal of Marketing Research, Vol. 14 No. 3, pp. 396-402.

Ashforth, B. and Mael, F. (1989), "Social identity theory and the organization", The Academy of Management Review, Vol. 14 No. 1, pp. 20-39.

Auger, P., Devinney, T.M., Dowling, G.R., Eckert, C., and Lin, N. (2013), "How much does a company's reputation matter in recruiting?", MIT Sloan Management Review, Vol. 54 No. 4, pp. 79-88.

Bartel, C. (2001), "Social comparisons in boundary-spanning work: effects of community outreach on members' organizational identity and identification", Administrative Science Quarterly, Vol. 46 No. 3, pp. 379-413.

Bagozzi, R.P. and Yi, Y. (1990), "Assessing method variance in multitrait- multimethod matrices: the case of self-reported affect and perceptions at work", Journal of Applied Psychology, Vol. 75 No. 5, pp. 547-60.

Bhattacharya, C., Korschun, D. and Sen, S. (2009), "Strengthening stakeholder-company relationships through mutually beneficial corporate social responsibility initiatives", Journal of Business Ethics, Vol. 85 No. 2, pp. 257-72.

Bhattacharya, C., Sen, S. and Korschun, D. (2008), "Using corporate social responsibility to win the war for talent”, Sloan Management Review, Vol. 49 No. 2, pp. 37-44.

Bitner, M. (1990), "Evaluating service encounters: the effects of physical surroundings and employee responses", Journal of Marketing, Vol. 54 No. 2., pp. 69-82.

Boulding, K. E. (1956), "General systems theory - the skeleton of science", Management Science, Vol. 2 No. 3, pp. 197-208.

Bowen, H. (1953), Social responsibilities of the businessman, Harper \& Row, New York.

Brokaw, L. (2009), "Does sustainability change the talent equation?", MIT Sloan Management Review, Vol. 51 No. 1, pp. 33-34. 
Campbell, J. (2007), "Why would corporations behave in socially responsible ways? An institutional theory of corporate social responsibility", The Academy of Management Review, Vol. 32 No. 3, pp. 946-67.

Carroll, A. (1999), "Corporate social responsibility: evolution of a definitional construct", Business and Society, Vol. 38 No. 3, pp. 268-95.

Chathoth, P., Mak, B., Jauhari, V. and Manaktola, K. (2007), "Employees' perceptions of organizational trust and service climate: a structural model combining their effects on employee satisfaction", Journal of Hospitality and Tourism Research, Vol. 33 No. 3, pp. 338-57.

Chen, J. and Roberts, R. (2010), "Toward a more coherent understanding of the organizationsocietal relationship: a theoretical consideration for social and environmental accounting research", Journal of Business Ethics, Vol. 97 No. 4, pp. 651-65.

Chen, P.-J. and Choi, Y. (2008), “Generational differences in work values: a study of hospitality management", International Journal of Contemporary Hospitality Management, Vol. 20, No. 6, pp. 595-615.

Chi, C. and Gursoy, D. (2009), "Employee satisfaction, customer satisfaction, and financial performance: an empirical examination”, International Journal of Hospitality Management, Vol. 28 No. 2, pp. 245-53.

Clark, R., Hartline, R. and Jones, K. (2008), “The effects of leadership style on hotel employees' commitment to service quality", Cornell Hospitality Quarterly, Vol. 50 No. 2, pp. 20931 .

Clarkson, M. (1995), “A stockholder framework for analyzing and evaluating corporate social performance", The Academy of Management Review, Vol. 20 No. 1, pp. 92-117.

Cochran, P. (2007), “The evolution of corporate social responsibility”, Business Horizons, Vol. 50 No. 6, pp. 449-54.

Collier, J. and Esteban, R. (2007), "Corporate social responsibility and employee commitment", Business Ethics: A European Review, Vol. 16 No. 1, pp. 19-33.

Davis, J., Schoorman, F. and Donaldson, L. (1997), “Toward a stewardship theory of management", Academy of Management Review, Vol. 22 No. 1, pp. 20-47.

Diener, M., Parekh, A., Pitera, J. and Hoffman, A. (2009), High performance hospitality: Sustainable hotel case studies, American Hotel \& Lodging Educational Institute, Washington D.C.

Dodd, Jr., E.M. (1932), "For whom are corporate managers trustees?”, Harvard Law Review, Vol. 45 No. 7, pp. 1145-63. 
Dutton, J., Dukerich, J. and Harquail, C. (1994), “Organizational image and member identification", Administrative Science Quarterly, Vol. 39 No. 2, pp. 239-63.

Freeman, R.E. (1984), Strategic management: a stakeholder approach, Pitman, Boston.

Freeman, R. E. and Liedtka, J. (1991), "Corporate social responsibility: A critical approach." Business Horizons, Vol. July-August, pp. 92-98.

Friedman, M. (1970). "The Social Responsibility of Business is to Increase its Profits," New York Times, September 13, pp. 122-126.

Galbreath, J. (2010), "How does corporate social responsibility benefit firms? Evidence from Australia", European Business Review, Vol. 22 No. 4, pp. 411-31.

Gautam, T., Dick, R. and Wagner, U. (2004), Organizational identification and organizational commitment: distinct aspects of two related concepts", Asian Journal of Social Psychology, Vol. 7 No. 3, pp. 301-15.

Greening, D.W. and Turban, D.B. (2000), "Corporate social performance as a competitive advantage in attracting a quality workforce", Business and Society, Vol. 39 No. 3, pp. 254-80.

Guillet, B. and Mattila, A. (2010), "A descriptive examination of corporate governance in the hospitality industry", International Journal of Hospitality Management, Vol. 29 No. 4, pp. 677-84.

Hartline, M. and Jones, K. (1996), "Employee performance cues in a hotel service environment: influence on perceived service quality, value, and word-of-mouth intentions", Journal of Business Research, Vol. 35 No. 3, pp. 207-15.

Heskett, J., Jones, T., Loveman, G., Sasser, W. and Schlesinger, L. A. (2008), "Putting the service-profit chain to work", Harvard Business Review, Vol. 87 No. 7, pp. 118-28.

Holcomb, J. L., Upchurch, R. S. and Okumus, F. (2007), "Corporate social responsibility: what are top hotel companies reporting?", International Journal of Contemporary Hospitality Management, Vol. 19, No. 6, pp. 461-75.

Holcomb, J. L., Okumus, F. and Bilgihan, A. (2010), "Corporate social responsibility: what are the top three Orlando theme parks reporting?", Worldwide Hospitality and Tourism Themes, Vol. 2, No. 3, pp. 316-37.

Husted, B. and Allen, D. (2006), "Corporate social responsibility in the multinational enterprise: strategic and institutional approaches", Journal of International Business Studies, Vol. 37, pp. 838-49. 
Jennings, P. and Zandbergen, P. (1995), "Ecologically sustainable organizations: an institutional approach", Academy of Management Review, Vol. 20, No. 4, pp. 1015-52.

Jones, T. (1995), “Instrumental stakeholder theory: a synthesis of ethics and economics", Academy of Management Review, Vol. 20, No. 2, pp. 404-37.

Karatepe, O. and Kilic, H. (2007), "Relationships of supervisor support and conflicts in the work-family interface with the selected job outcomes of frontline employees", Tourism Management, Vol. 28 No. 1, pp. 238-52.

Kelman, H. (1958), "Compliance, identification, and internalization: three processes of attitude change”, Journal of Conflict Resolution, Vol. 2 No. 1, pp. 51-60.

Kim, H-R., Lee, M., Lee, H.T., Kim, N-M. (2010), “Corporate social responsibility and employee-company identification”, Journal of Business Ethics, Vol. 95 No. 4, pp. 557569.

King, C., Funk, D.C. and Wilkins, H. (2011), "Bridging the gap: an examination of the relative alignment of hospitality research and industry priorities", International Journal of Hospitality Management, Vol. 30 No. 1, 157-66.

Kiron, D., Kruschwitz, N., Reeves, M. and Goh, E. (2013). "The benefits of sustainability-driven innovation," MIT Sloan Management Review, Vol. 54, No. 2, pp. 69-73.

Levy, S.E. and Park, S-Y. (2011), "An analysis of CSR activities in the lodging industry", Journal of Hospitality and Tourism Management, Vol. 18 No. 1, pp. 147-54.

Levitt, T. (1958), “The dangers of social responsibility.” Harvard Business Review, Vol. September-October, pp. 41-50.

Lindgreen, A., Swaen, V. and Johnston, W. (2009), "Corporate social responsibility: an empirical investigation of U.S. organizations”, Journal of Business Ethics, Vol. 85 No. 2, pp. 303-23.

Lozar Manfreda, K., Bosnjak, M., Berzelak, J., Haas, I. and Vehovar, V. (2008), "Web surveys versus other survey modes: a meta-analysis comparing response rates", International Journal of Market Research, Vol. 50 No. 1, pp. 79-104.

Liao, H. and Chuang, A. (2004), "A multilevel investigation of factors influencing employee service performance and customer outcomes", The Academy of Management Journal, Vol. 47 No. 1, pp. 41-58.

Lub, X., Bijvank, M. N., Bal, P. M., Blomme, R., Schalk, R. (2012), “Different or alike? Exploring the psychological contract and commitment of different generations of hospitality workers", International Journal of Contemporary Hospitality Management, Vol. 24, No. 4, pp. 553-73. 
Mael, F. and Ashforth, B. (1992), "Alumni and their alma mater: a partial test of the reformulated model of organizational identification", Journal of Organizational Behavior, Vol. 13 No. 2, pp. 103-23.

Mael, F. and Tetrick, L. (1992), "Identifying organizational identification", Educational and Psychological Measurement, Vol. 52 No. 4, pp. 813-24.

Maignan, I., Ferrell, O. and Hult, G. (1999), “Corporate citizenship: cultural antecedents and business benefits", Academy of Marketing Science Journal, Vol. 27 No. 4, pp. 455-69.

McWilliams, A. and Siegel, D. (2001), "Corporate social responsibility: a theory of the firm perspective", Academy of Management Review, Vol. 26 No. 1, pp. 117-27.

Murray, K. and Vogel, C. (1997), "Using a hierarchy-of-effects approach to gauge the effectiveness of corporate social responsibility to generate goodwill toward the firm: financial versus nonfinancial impacts", Journal of Business Research, Vol. 38 No. 2, pp. 141-59.

Peterson, D. (2004), "The relationship between perceptions of corporate citizenship and organizational commitment", Business Society, Vol. 43 No. 3, pp. 296-319.

Podsakoff, P.M., MacKenzie, S., Lee, J-Y. and Podsakoff, N. (2003), “Common method biases in behavioral research: a critical review of the literature and recommended remedies", Journal of Applied Psychology, Vol. 88 No. 5, pp. 879-903.

Pohle, G. and Hittner, J. (2008), “Attaining sustainable growth through corporate social responsibility", available at: http://www935.ibm.com/services/us/gbs/bus/pdf/gbe03019-usen-02.pdf (accessed 26 January 2013).

Porter, M.E. and Kramer, M.R. (2006), "Strategy \& society: the link between competitive advantage and corporate social responsibility", Harvard Business Review, Vol. 84 No. 12, pp. 78-92.

Porter, M. E. and Kramer, M. R. (2011), "Creating shared value.” Harvard Business Review, Vol. 89, pp. 62-77.

PricewaterhouseCoopers. (2011), "Millennials at work: Reshaping the workplace", available at http://www.pwc.com/gx/en/managing-tomorrows-people/future-of-work/download.jhtml (accessed 24 April 2012).

Ralston, E. (2010), “Deviance or norm? Exploring corporate social responsibility”, European Business Review, Vol. 22 No. 4, pp. 397-410.

Rego, A., Leal, S., Cunha, M., Faria, J. and Pinho, C. (2010), "How the perceptions of five dimensions of corporate citizenship and their inter-inconsistencies predict affective 
commitment", Journal of Business Ethics, Vol. 94 No. 1, pp. 107-27.

Riketta, M. (2005), “Organizational identification: a meta-analysis", Journal of Vocational Behavior, Vol. 66 No. 2, pp. 358-84.

Roberts, R. (1992), "Determinants of corporate social responsibility disclosure: an application of stakeholder theory", Accounting, Organizations and Society, Vol. 17, No. 6, pp. 595-612.

Rupp, D., Ganapathi, J., Aguilera, R. and Williams, C. (2006), "Employee reactions to corporate social responsibility: an organizational justice framework", Journal of Organizational Behavior, Vol. 27 No. 4, pp. 537-43.

Russo, M. and Fouts, P. (1997), “A resource-based perspective on corporate environmental performance and profitability", Academy of Management Journal, Vol. 40, No. 3, pp. $534-59$.

Sheldon, P. and Park, S-Y. (2011), "An exploratory study of corporate social responsibility in the U.S. travel industry", Journal of Travel Research, Vol. 50 No. 4, pp. 392-407.

Shropshire, C. and Hillman, A. (2007), "A longitudinal study of significant change in stakeholder management", Business and Society, Vol. 46, No. 1, pp. 63-87.

Singh, A.J. and Houdre, H. (2012), Hotel sustainable development: Principles and best practices, American Hotel \& Lodging Educational Institute, Washington D.C.

Smith, A., Bolton, R. and Wagner, J. (1999), A model of customer satisfaction with service encounters involving failure and recovery", Journal of Marketing Research, Vol. 36 No. 3, pp. 356-72.

Spiller, R. (2000), "Ethical business and investment: a model for business and society", Journal of Business Ethics, Vol. 27 No.1-2, pp. 149-60.

Tajfel, H. and Turner, J. (1986), "The social identity theory of intergroup behavior", in Worchel, S. and Austin, W. (Eds.), Psychology of Intergroup Relations, Nelson, Chicago, pp. 7-24.

Tepeci, M. (1999), "Increasing brand loyalty in the hospitality industry", International Journal of Contemporary Hospitality Management, Vol. 11 No. 5, pp. 223-30.

Tsaur, S. and Lin, Y. (2004), "Promoting service quality in tourist hotels: the role of HRM practices and service behavior", Tourism Management, Vol. 25 No. 4, pp. 471-81.

Turban, D. and Greening, D. (1997), "Corporate social performance and organizational attractiveness to prospective employees", Academy of Management Journal, Vol. 40 No. 3, pp. 658-72.

Turker, D. (2009a), "Measuring corporate social responsibility: a scale development study", 
Journal of Business Ethics, Vol. 85 No. 4, pp. 411-27.

Turker, D. (2009b), "Measuring how corporate social responsibility influences organizational commitment", Journal of Business Ethics, Vol. 89 No. 2, pp. 198-204.

Turner, J. (1984), "Social identification and psychological group formation", in Tajfel, H. (Ed.), The Social Dimension: European Developments in Social Psychology, Cambridge University Press, England, pp. 518-38.

U.S. Bureau of Labor Statistics (2011), “Job openings and labor turnover survey”, available at: http://www.bls.gov/jlt/home.htm (accessed 21 December 2012).

Van Dick, R., Christ, O., Stellmacher, J., Wagner, U., Ahlswede, O., Grubba, C., Hauptmeier, M., Höhfeld, C., Moltzen, K. and Tissington, P. (2004), "Should I stay or should I go? Explaining turnover intentions with organizational identification and job satisfaction", British Journal of Management, Vol. 15 No. 4, pp. 351-60.

Van Dick, R., Wagner, U., Stellmacher, J., Christ, O. and Tissington, P. (2005), "To be (long) or not to be (long): social identification in organizational contexts", Genetic, Social, and General Psychology Monographs, Vol. 131 No. 3, pp. 189-218.

Van Knippenberg, D. (2000), "Work motivation and performance: a social identity perspective", Applied Psychology, Vol. 49 No. 3, pp. 357-71.

Waddock, S. (2004), "Parallel universes: companies, academics, and the progress of corporate citizenship", Business and Society Review, Vol. 109 No. 1, pp. 5-42.

Wernau, J. (2010), "Group cancels conference at two Hilton hotels a day before Chicago workers go on strike", available at http://articles.chicagotribune.com/2010-12-16/business/ct-biz1217-palmer-strike-20101216_1 hotel-workers-annemarie-strassel-hotel-industry (accessed 24 December 2012).

Wheeler, D., Colbert, B. and Freeman, R. E. (2003), "Focusing on value: reconciling corporate social responsibility, sustainability, and a stakeholder approach in a network world", Journal of General Management, Vol. 28, No. 3, pp. 1-28.

Wood, D. (1991), “Corporate social performance revisited", Academy of Management, Vol. 16 No. 4, pp. 691-718.

Wood, D. (2010), "Measuring corporate social performance: a review", International Journal of Management Reviews, Vol. 2 No. 1, pp. 50-84.

Zukin, C. and Szeltner, M. (2012), "Talent report: What workers want in 2012", http://www.netimpact.org/whatworkerswant (accessed 10 April 2013). 